\title{
REVIEW
}

Open Access

\section{Epidemiology of Taenia saginata taeniosis/ cysticercosis: a systematic review of the distribution in the Americas}

\author{
Uffe Christian Braae ${ }^{1 *}$ D, Lian F. Thomas ${ }^{2,3}$, Lucy J. Robertson ${ }^{4}$, Veronique Dermauw ${ }^{5}$, Pierre Dorny 5,6 , \\ Arve Lee Willingham ${ }^{1}$, Anastasios Saratsis ${ }^{7}$ and Brecht Devleesschauwer ${ }^{8,9}$
}

\begin{abstract}
Background: The distribution of Taenia saginata in the Americas is unclear. Establishing the distribution, economic burden, and potentials for control of bovine cysticercosis is increasingly important due to the growing demand for beef. This paper aims to take the first step and reviews the recent distribution of $T$. saginata taeniosis and bovine cysticercosis on a national level within the Americas.

Methods: We undertook a systematic review of published and grey literature for information on the occurrence, prevalence, and geographical distribution of bovine cysticercosis and human taeniosis in the 54 countries and territories of the Americas between January 1st, 1990 and December 31st, 2017. Data on bovine cysticercosis from OIE reports from 1994 to 2005 were also included.

Results: We identified 66 papers from the Americas with data on the occurrence of taeniosis or bovine cysticercosis and an additional 19 OIE country reports on bovine cysticercosis. Taeniosis was reported from 13 countries, with nine of these countries reporting specifically T. saginata taeniosis, and four countries reporting non-species specific taeniosis. The reported prevalence of taeniosis ranged between $0.04-8.8 \%$. Bovine cysticercosis was reported from 19 countries, nine identified through the literature search, and an additional 10 identified through the OIE country reports for notifiable diseases. The reported prevalence of bovine cysticercosis ranged between $0.1-19 \%$. Disease occurrence was restricted to 21 countries within the Americas, the majority from the mainland, with the only island nations reporting either bovine cysticercosis or taeniosis being Cuba, Haiti, and the US Virgin Islands.

Conclusions: Taenia saginata is widely distributed across 21 of the 54 countries in the Americas, but insufficient epidemiological data are available to estimate the subnational spatial distribution, prevalence, incidence and intensity of infections. This needs to be addressed through active surveillance and disease detection programmes. Such programmes would improve the data quantity and quality, and may enable estimation of the economic burden due to bovine cysticercosis in the region in turn determining the requirement for and cost-effectiveness of control measures.
\end{abstract}

Keywords: Taenia saginata, Cestoda, Beef tapeworm, Taeniosis, Bovine cysticercosis, North and South America, Caribbean

\footnotetext{
* Correspondence: UBraae@rossvet.edu.kn

${ }^{1}$ One Health Center for Zoonoses and Tropical Veterinary Medicine, Ross

University School of Veterinary Medicine, P.O. Box 334, Basseterre, Saint Kitts

and Nevis

Full list of author information is available at the end of the article
}

(c) The Author(s). 2018 Open Access This article is distributed under the terms of the Creative Commons Attribution 4.0 International License (http://creativecommons.org/licenses/by/4.0/), which permits unrestricted use, distribution, and reproduction in any medium, provided you give appropriate credit to the original author(s) and the source, provide a link to the Creative Commons license, and indicate if changes were made. The Creative Commons Public Domain Dedication waiver (http://creativecommons.org/publicdomain/zero/1.0/) applies to the data made available in this article, unless otherwise stated. 


\section{Background}

Taenia saginata is a zoonotic tapeworm that is of economic importance in countries where cattle are kept. The parasite is transmitted from human tapeworm carriers (taeniosis) to bovines (cysticercosis) by excretion of eggs or proglottids containing eggs into the environment via the stool. Bovines can then ingest the eggs through contaminated feed or water. After ingestion, the eggs hatch and release oncospheres in the small intestines, where the oncospheres penetrate the intestinal wall to reach the blood circulation. This distributes them throughout the body, but primarily to muscle tissue, where they develop into cysticerci. For humans to become infected with $T$. saginata, raw or undercooked bovine meat or offal containing infective cysts must be consumed. Bovine cysticercosis has been associated with various environmental factors related to water sources, such as animals having access to surface water, flooding of pastures and proximity to wastewater sources [1].

Taeniosis causes only a few, if any, mild symptoms in humans [2], and bovine cysticercosis is usually asymptomatic. The primary burden of the parasite is therefore the economic burden imposed on the cattle industry. Economic losses occur when infected carcasses are identified during routine meat inspection at slaughter facilities, causing total economic loss if the carcass is condemned due to high intensity infection, or partial economic loss if extra-processing of the carcass is required due to low intensity infection. Additional costs may include increased labour costs due to extra-handling and transport of infected carcasses to appropriate facilities, in addition to, potential freezing, transport and processing of the meat. However, the current economic burden due to bovine cysticercosis in the Americas has not been estimated.

Post-mortem inspection procedures of carcasses for pathogens vary from country to country, and even from facility to facility in some countries. In general, however, this diagnostic method has low sensitivity for detection of bovine cysticercosis [3-5]. Nevertheless, routine meat inspection remains the preferred tool for $T$. saginata detection in bovines. There is currently no ante-mortem test that performs with high sensitivity and high specificity, regardless of infection intensity. The sensitivities of existing serological tests are highly dependent on the infection intensity within the host [6], with the tests becoming increasingly unreliable as infection intensity decreases. The lack of a 'gold standard', combined with the non-specific symptomatic/asymptomatic nature of the diseases caused by the parasite in humans and bovines, and the prolonged survival of $T$. saginata eggs in the environment [7], makes T. saginata difficult to control.
Taenia saginata is thought to be widely distributed throughout the world, and to a larger degree in low-income countries where hygiene and sanitation standards are below average and routine meat inspection not always enforced. Nonetheless, in countries where standards of hygiene and sanitation are considered high and routine meat inspection enforced, such as within Europe, bovine cysticercosis still remains widely distributed [8]. There is no clear overview of the distribution of this zoonotic cestode in the Americas, and with a growing demand for beef, establishing the distribution, prevalence, economic burden, and potentials for control is more important than ever. This paper aims to take the first step, and reviews the distribution of T. saginata taeniosis and bovine cysticercosis on a national level within the Americas between 1990 and 2017.

\section{Methods}

\section{Search strategy}

We undertook a systematic review of published literature for information on the occurrence, prevalence, and geographical distribution of bovine cysticercosis and human taeniosis in the Americas between January 1st, 1990 and December 31st, 2017, using an approach that followed PRISMA guidelines [9]. The protocol and the PRISMA checklist for this review can be found in Additional file 1. The Americas for the purpose of this review included the following 54 countries or territories: Anguilla, Antigua \& Barbuda, Argentina, Aruba, Bahamas, Barbados, Belize, Bermuda, Bolivia, Brazil, British Virgin Islands, Canada, Caribbean Netherlands, Cayman Islands, Chile, Colombia, Costa Rica, Cuba, Curacao, Dominica, Dominican Republic, Ecuador, El Salvador, Falkland Islands, French Guiana, Greenland, Grenada, Guadeloupe, Guatemala, Guyana, Haiti, Honduras, Jamaica, Martinique, Mexico, Montserrat, Nicaragua, Panama, Paraguay, Peru, Puerto Rico, Saint Barthélemy, Saint Kitts \& Nevis, Saint Lucia, Saint Martin, Saint Pierre \& Miquelon, Saint Vincent \& the Grenadines, Suriname, Trinidad \& Tobago, Turks \& Caicos Islands, Uruguay, US Virgin Islands, USA and Venezuela.

The first search was done in PubMed (http://www. ncbi.nlm.nih.gov/pubmed), using the following search phrase: (cysticerc* OR cisticerc* OR "C. bovis" OR taenia* OR tenia* OR saginata OR taeniosis OR teniosis OR taeniasis OR ténia OR taeniid OR cysticerque OR Taeniarhynchus) AND (America OR USA OR Brazil OR Argentina OR Canada OR Peru OR Chile OR Ecuador OR Bolivia OR Paraguay OR Costa Rica OR Uruguay OR Bermuda OR Greenland OR Caribbean Netherlands OR Saint Barts OR Saint Pierre and Miquelon OR Falkland Islands OR Anguilla OR Antigua and Barbuda OR 
Aruba OR Bahamas OR Barbados OR Belize OR Bonaire OR British Virgin Islands OR Bermuda OR Cayman Islands OR Colombia OR Costa Rica OR Cuba OR Curaçao OR Dominica OR Dominican Republic OR El Salvador OR French Guiana OR Grenada OR Guadeloupe OR Guatemala OR Guyana OR Haiti OR Honduras OR Jamaica OR Martinique OR Mexico OR Montserrat OR Netherlands Antilles OR Nicaragua OR Panama OR Puerto Rico OR Saba OR Saint Kitts and Nevis OR Saint Lucia OR Saint Vincent and the Grenadines OR Saint Eustatius OR Sint Maarten OR Saint Martin OR Suriname OR Trinidad and Tobago OR Turks and Caicos Islands OR US Virgin Islands OR Venezuela). The following databases were also searched using keywords from the above search phrase: Web of Science (www.webofknowledge.com), OpenGrey (http://www.opengrey.eu/), and CABDirect (http://www.cabdirect.org/).

\section{Selection criteria}

Outputs from the databases searches were compiled and screened for duplicates. Thereafter, titles and abstracts were screened for eligibility and were excluded on the following grounds: (i) studies concerning a parasite other than $T$. saginata; (ii) studies reporting data from countries different from those listed above; (iii) studies published prior to January 1st, 1990 or after December 31st, 2017; (iv) studies reporting results outside the scope of the review question (e.g. laboratory experiments, environmental studies and general reviews); and (v) duplicated data. If the same data had been published more than once, the oldest article was included and all others omitted. Full text manuscripts were then retrieved where possible and assessed by the same criteria as above (Fig. 1). The citations in identified reports were also screened for relevant literature.

Data on bovine cysticercosis from OIE reports from 1994 to 2005 were also obtained [10, 11]. Additionally, we sought to obtain data from known articles not captured in the literature database searches, as well as unpublished work (i.e. masters' theses) and these were included if they confirmed presence of $T$. saginata from a country where no disease report had been identified in the literature search, or if prevalence data were presented at a higher geographical resolution to that in the published literature.

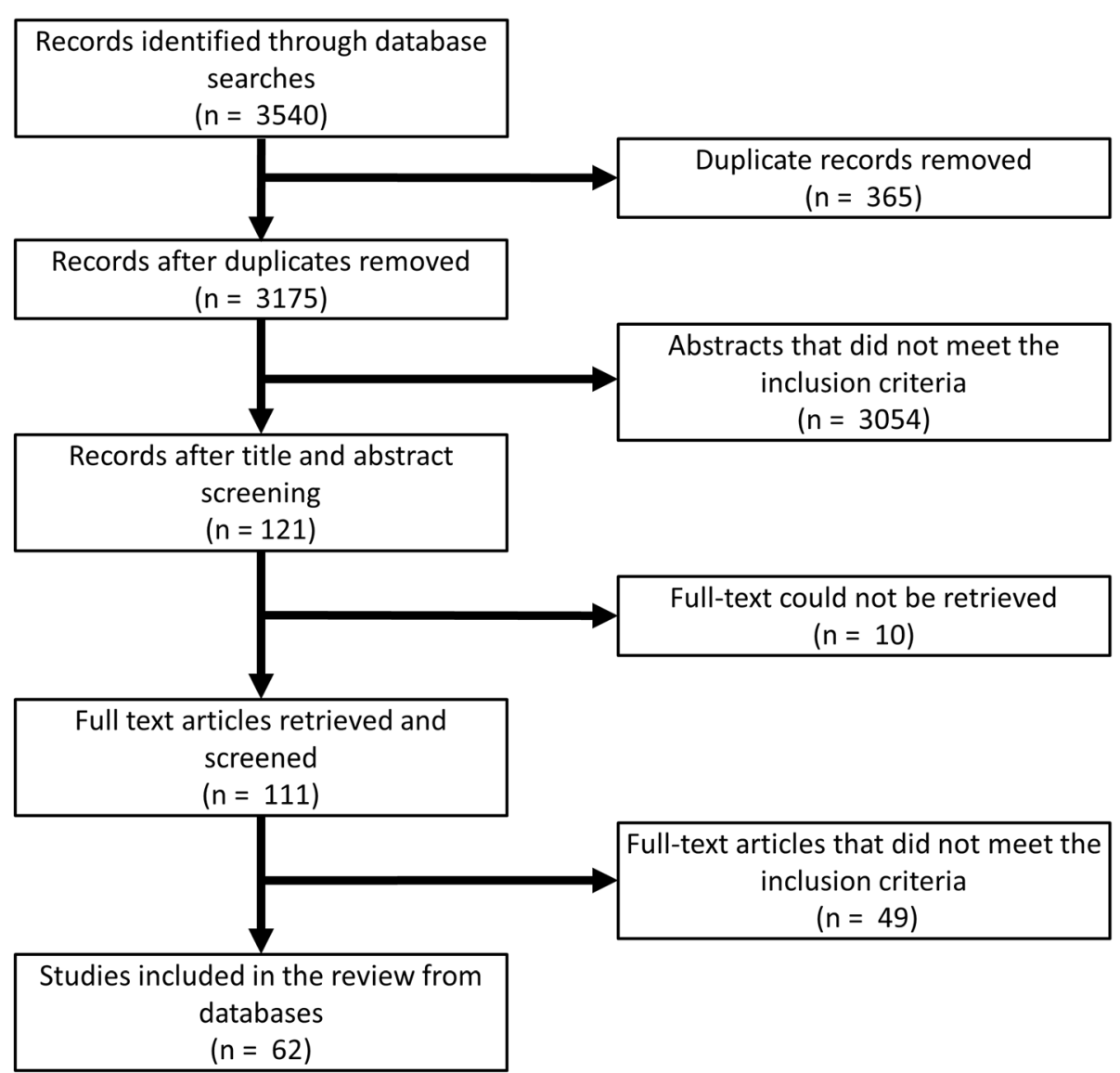

Fig. 1 Flow diagram of the database searches 


\section{Data extraction and generation}

From the included literature and reports, data were extracted into predefined tables that can be found in Additional file 2: Tables S1-S3. Prevalence data were only extracted if both the numerator and the denominator were provided, and 95\% confidence intervals using the Clopper-Pearson method, were calculated, if not already stated within the paper. All maps were generated using ArcGIS 10.3.1 (ESRI Inc., USA).

\section{Results}

\section{Search results}

The database searches yielded 62 articles presenting data on taeniosis or bovine cysticercosis in the Americas. An additional four articles were identified from other sources and confirmed occurrence of taeniosis in Venezuela, and occurrence of bovine cysticercosis in the USA and the US Virgin Islands. Of the 66 articles identified, 31 reported occurrences of taeniosis, 33 reported occurrences of bovine cysticercosis, and two papers reported occurrences of both diseases. A total of 19 OIE country reports were also identified. All eligible references are listed within the tables of this paper.

\section{Taeniosis and bovine cysticercosis occurrence}

In the period 1990-2017, taeniosis or bovine cysticercosis has been reported within all mainland countries in the Americas except for Belize, French Guiana, Guyana, Panama and Suriname. The only island nations within the region to report any disease occurrence during the study period were Cuba, Haiti and the US Virgin Islands, contributing to occurrence of the parasite in a total of 21 countries within the Americas.

\section{Human taeniosis occurrence}

In the period 1990-2017, taeniosis was reported in 13 countries in the Americas, with T. saginata taeniosis reported in nine of those countries (Fig. 2). Colombia, Haiti, Venezuela and the USA reported taeniosis, but the specific tapeworm species were not confirmed in any of the reports. In seven countries there were reports of bovine cysticercosis, but no reports of taeniosis. In total, 33 papers reporting the occurrence of taeniosis within the Americas were identified in the search strategy. Of the 33 papers, there were three case reports of taeniosis, with species identification done in two of these cases, Chile and Mexico (Table 1). In the case reports from Brazil and Chile, it was unclear exactly when the infection had been discovered.

Of the 33 papers, seven contained insufficient data, or the data were of insufficient quality to yield prevalence estimations (Table 2). In the majority of these studies, species identification was performed, but the diagnostic method was not always described.

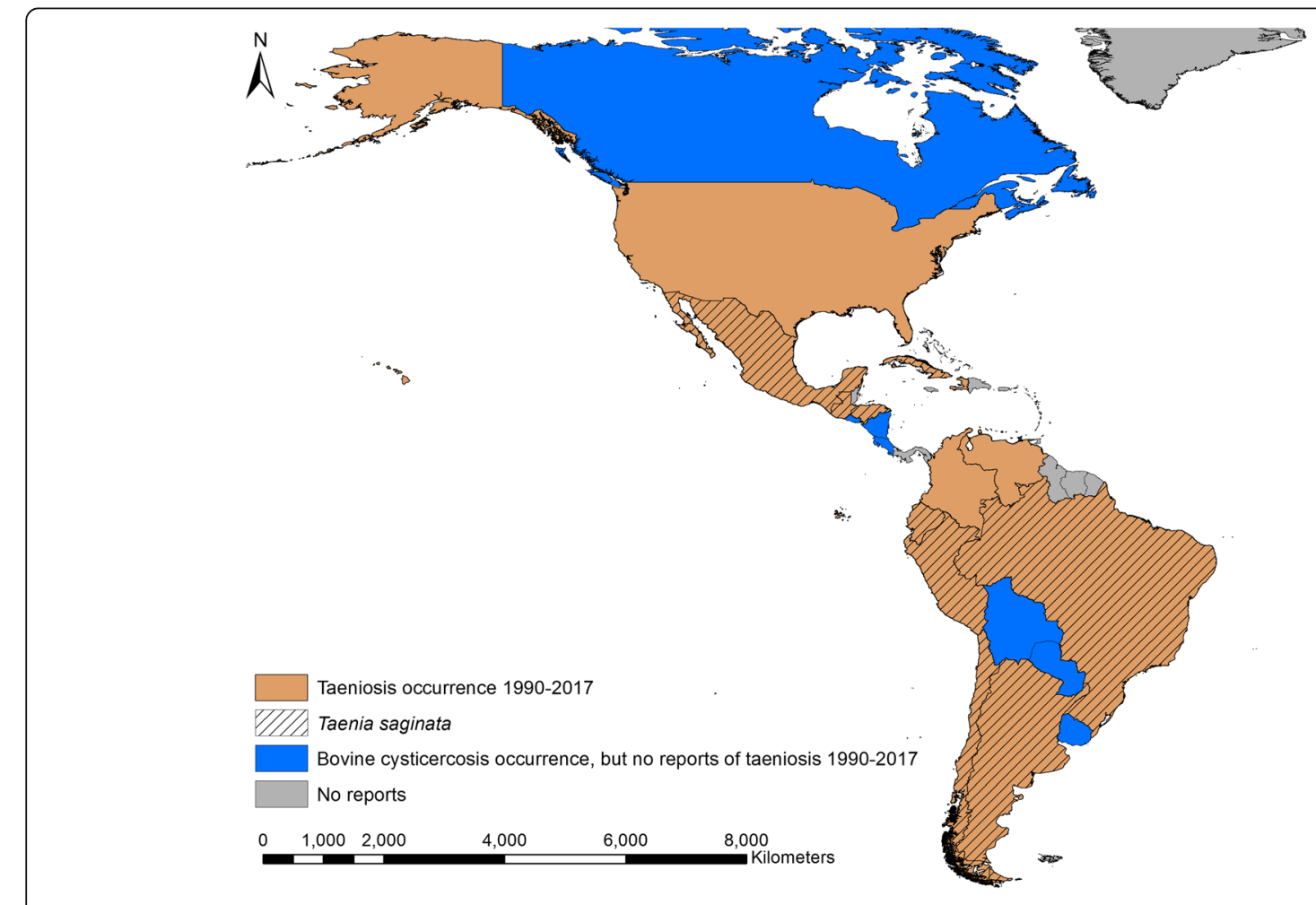

Fig. 2 Countries with reports of taeniosis due to Taenia saginata and Taenia spp. in the period 1990-2017 
Table 1 Individual cases of human taeniosis (published case studies)

\begin{tabular}{lcclll}
\hline Country & Year & Nationality & Species $^{\text {a }}$ & $\begin{array}{l}\text { Diagnostic } \\
\text { technique }\end{array}$ & Reference \\
\hline Brazil & na & Brazilian & $\begin{array}{l}\text { Taenia } \\
\text { spp. }\end{array}$ & $\begin{array}{l}\text { Proglottid } \\
\text { identification }\end{array}$ & {$[27]$} \\
Chile & na & na & $\begin{array}{l}\text { T. } \\
\text { saginata }\end{array}$ & $\begin{array}{l}\text { Proglottid } \\
\text { identification }\end{array}$ & {$[28]$} \\
Mexico & \multirow{2}{*}{2006} & na & $\begin{array}{l}\text { T. } \\
\text { saginata }\end{array}$ & $\begin{array}{l}\text { Proglottid } \\
\text { identification }\end{array}$ & {$[29]$} \\
\hline
\end{tabular}

Abbreviation: na information not provided

alf confirmed

In 23 papers, the methodology and data were sufficiently described to enable prevalence and confidence interval calculations (Table 3). In the majority, disease confirmation was based on various microscopic methods. Prevalence reports ranged from between 0.04$8.8 \%$. All 23 studies reported data that could be georeferenced to first-level administration.

\section{Bovine cysticercosis}

Bovine cysticercosis was reported from 19 countries within the Americas during the period 1990-2017. The literature search identified nine countries with bovine cysticercosis, and an additional 10 countries were identified through the 1994 and 2005 OIE country reports for notifiable diseases [10,11]. Taenia saginata was reported from humans in both Guatemala and Peru during 19902017 , but no reports of bovine cysticercosis could be obtained from these two countries (Fig. 3). Cuba, Haiti and the US Virgin Islands were the only island nations/territories to report bovine cysticercosis during the study period. On the mainland most countries reported bovine cysticercosis, but no reports could be found from Belize, French Guiana, Guyana, Suriname and Panama. Of the 35 papers identified that reported occurrence of bovine cysticercosis, seven did not contain sufficient data for prevalence calculations. All seven papers reported results of official meat inspections in Brazil, Chile, Cuba, the USA and the US Virgin Islands, respectively (Table 4).
In total, 28 papers contained sufficient information to calculate prevalence and 95\% confidence intervals (Table 5). Most of the studies (82\%) originated from Brazil, where reported prevalence ranged between $0.1-19 \%$, with both ends of this range obtained by routine meat inspection. Overall, the majority of the studies reported official meat inspection data, but antibody detection (by Ab-ELISA or immunoblot, studies in Brazil) and antigen detection (Ag-ELISA, study in Ecuador) were also used as diagnostic techniques.

Brazil was the only country, where data on bovine cysticercosis could be obtained from several regions of the country. In the period 1990-2017, bovine cysticercosis was reported in $70 \%(19 / 27)$ of the states (first-level administration) in Brazil. As an illustration of risk of bovine cysticercosis, Fig. 4 shows the 2006 modelled density of cattle in Brazil [12], overlaid with the 19 states from where bovine cysticercosis was reported during 1990-2017.

\section{Discussion}

This review shows that $T$. saginata is widely distributed across the Americas. Taeniosis was widely reported, but not always at the species level. The estimation of the distribution and the prevalence of taeniosis is severely complicated by the lack of specific symptoms in tapeworm carriers [2], and the fact that the disease is not commonly notifiable. Some studies differentiated between $T$. saginata taeniosis and the much more dangerous infection, $T$. solium taeniosis. This was usually done in studies with a research objective where the study outcome was dependent on the species differentiation. In health care and routine screening, this information is seen to be of less importance to the physicians attending as the anthelminthic treatments prescribed to patients will be effective against either parasite species [13, 14], despite the risk of cysticercosis transmission to either the carrier or their family members if T. solium is present.

The majority of the taeniosis infections reported had been identified by microscopic examination for the presence of Taenia spp. eggs, which has low sensitivity [15], and cannot be used for determining the diagnosis to

Table 2 Aggregated cases of human taeniosis (hospital/laboratory/field records without prevalence data)

\begin{tabular}{|c|c|c|c|c|c|}
\hline Country & Year & No. of cases & Species $^{a}$ & Diagnostic technique & Reference \\
\hline Brazil & na & na & Taenia spp. & Ritchie technique & [30] \\
\hline Colombia & 2009-2013 & na & T. saginata & na & [31] \\
\hline Honduras & na & 4 & T. saginata & Worm expulsion & [32] \\
\hline Peru & 2004-2007 & 16 & T. saginata & Worm expulsion & [33] \\
\hline Peru & 1998-2000 & 11 & T. saginata & Worm expulsion & [34] \\
\hline Venezuela & na & 1 & Taenia spp. & Ritchie technique & [35] \\
\hline Venezuela & 2004 & 18 & Taenia spp. & na & [36] \\
\hline
\end{tabular}

Abbreviation: na information not provided

af confirmed 
Table 3 Prevalence of human taeniosis (published data)

\begin{tabular}{|c|c|c|c|c|c|c|c|}
\hline Country & Year & Location of study ${ }^{a}$ & $\begin{array}{l}\text { Time } \\
\text { frame }\end{array}$ & $\begin{array}{l}\text { Prevalence (\%) } \\
(95 \% \mathrm{Cl})\end{array}$ & Species & Diagnostic technique & Reference \\
\hline Argentina & 1993 & Corrientes & Apr-Oct & $0.48(0.01-2.66)$ & $\begin{array}{l}T \text {. } \\
\text { saginata }\end{array}$ & Microscopy & [37] \\
\hline Argentina & 2005 & Corrientes & Mar-Dec & $1.77(0.22-6.25)$ & Taenia spp. & Graham tests & [38] \\
\hline Brazil & na & Minas Gerais & na & $0.18(0.13-0.26)$ & Taenia spp. & Kato-Katz & [39] \\
\hline Brazil & $\begin{array}{l}2000- \\
2001\end{array}$ & Minas Gerais & na & $0.04(0.03-0.05)$ & T. saginata & Worm expulsion & [40] \\
\hline Brazil & na & $\begin{array}{l}\text { Mato Grosso } \\
\text { do Sul }\end{array}$ & na & $2.24(0.46-6.40)$ & Taenia spp. & Microscopy & [41] \\
\hline Brazil & $\begin{array}{l}2004- \\
2006\end{array}$ & Paraná & Jun-May & $0.23(0.00-0.28)$ & Taenia spp. & Microscopy & [42] \\
\hline Brazil & 1992-1993 & Minas Gerais & Jan-Dec & $2.22(1.43-3.29)$ & Taenia spp. & Microscopy & [43] \\
\hline Brazil & 1992 & Minas Gerais & na & $0.72(0.46-1.07)$ & Taenia spp. & Microscopy & [44] \\
\hline Chile & $\begin{array}{l}2005- \\
2008\end{array}$ & Maule & Jan-Dec & $0.13(0.07-0.21)$ & Taenia spp. & Microscopy & [45] \\
\hline Colombia & 2004 & Bolívar & Feb-Jun & $0.79(0.16-2.28)$ & Taenia spp. & Microscopy & [46] \\
\hline \multirow[t]{2}{*}{ Ecuador } & \multirow[t]{2}{*}{2000} & Imbabura & \multirow[t]{2}{*}{ Jan-May } & $0.40(0.13-0.94)$ & \multirow[t]{2}{*}{ T. saginata } & \multirow{2}{*}{$\begin{array}{l}\text { Ritchie technique } \\
\& \text { worm expulsion }\end{array}$} & \multirow[t]{2}{*}{ [47] } \\
\hline & & Pichincha & & $2.30(1.32-3.71)$ & & & \\
\hline Guatemala & na & Jutiapa & na & $0.06(0.010 .33)$ & T. saginata & Worm expulsion & [48] \\
\hline Guatemala & 1991-1995 & Jutiapa & Oct-Jan & $0.03(0.01-0.16)$ & T. saginata ${ }^{b}$ & Copro-antigen ELISA & [49] \\
\hline Haiti & 2002 & Nationwide & na & $0.31(0.18-0.49)$ & Taenia spp. & Ritchie technique & [50] \\
\hline Honduras & na & Francisco Morazán & na & $0.25(0.01-1.37)$ & Taenia spp. & Ritchie technique & [51] \\
\hline Mexico & 2004 & Chihuahua & Aug-Dec & $1.02(0.21-2.96)$ & Taenia spp. & $\begin{array}{l}\text { Microscopy \& Copro-antigen } \\
\text { ELISA }\end{array}$ & [52] \\
\hline Mexico & 1992 & Baja California & Feb-Jul & 6.5 (2.43-13.66) & Taenia spp. & Microscopy & [53] \\
\hline Mexico & 1998 & Guerrero & na & $0.74(0.15-2.16)$ & Taenia spp. & Copro-antigen ELISA & [54] \\
\hline Mexico & 1996 & Morelos & na & $0.50(0.10-1.44)$ & Taenia spp. & $\begin{array}{l}\text { Copro-antigen ELISA } \\
\text { \& Ritchie technique }\end{array}$ & [55] \\
\hline Peru & 2008 & Ayacucho & na & $1.4(0.44-3.14)$ & Taenia spp. & Microscopy & [56] \\
\hline Peru & na & Tumbes & na & $1.5(0.55-3.22)$ & Taenia spp. & Copro-antigen ELISA & [57] \\
\hline USA & 2004 & Texas & Aug-Dec & $8.8(4.11-16.09)$ & Taenia spp. & $\begin{array}{l}\text { Microscopy \& Copro-antigen } \\
\text { ELISA }\end{array}$ & {$[52]$} \\
\hline Venezuela & na & Tachira & na & $0.8(0.02-4.31)$ & Taenia spp. & Ritchie technique & [58] \\
\hline
\end{tabular}

Abbreviations: $\mathrm{Cl}$ confidence interval, na information not provided

${ }^{a}$ First-level administration

${ }^{\mathrm{b}} \mathrm{No}$ description of species confirmation

species level. Prevalence of taeniosis ranged from very low levels to almost $9 \%$, which is very similar to previous reports of taeniosis prevalence $(0.01-10 \%)$ from Europe [16]. However, a direct comparison between studies is not appropriate, as variables such as study duration, recruitment criteria, diagnostic methods and standards of randomisation differ across studies. Clinical investigators should be encouraged to adopt a consensus protocol for collecting and analysing data for apparent taeniosis prevalence estimation, which would make comparison between studies and areas less biased.

It is clear from this review that bovine cysticercosis is widely distributed across the mainland of the Americas. It also indicates, however, a scarcity of recent data from the region. Taenia saginata taeniosis was reported from both Guatemala and Peru, but we were unable to identify any reports of bovine cysticercosis from either country. More than half of countries found to have bovine cysticercosis were found through the OIE databases $[10,11]$. However, bovine cysticercosis is no longer notifiable to the OIE, and the reporting, if any, is not standardised across the countries in the region. The occurrence of bovine cysticercosis could only be georeferenced to a first-level administration in five countries. This illustrates that for most of the countries where $T$. saginata is endemic, more data are needed to pinpoint areas of risk and areas with high transmission rates. Presence of bovine cysticercosis seems to be related to 


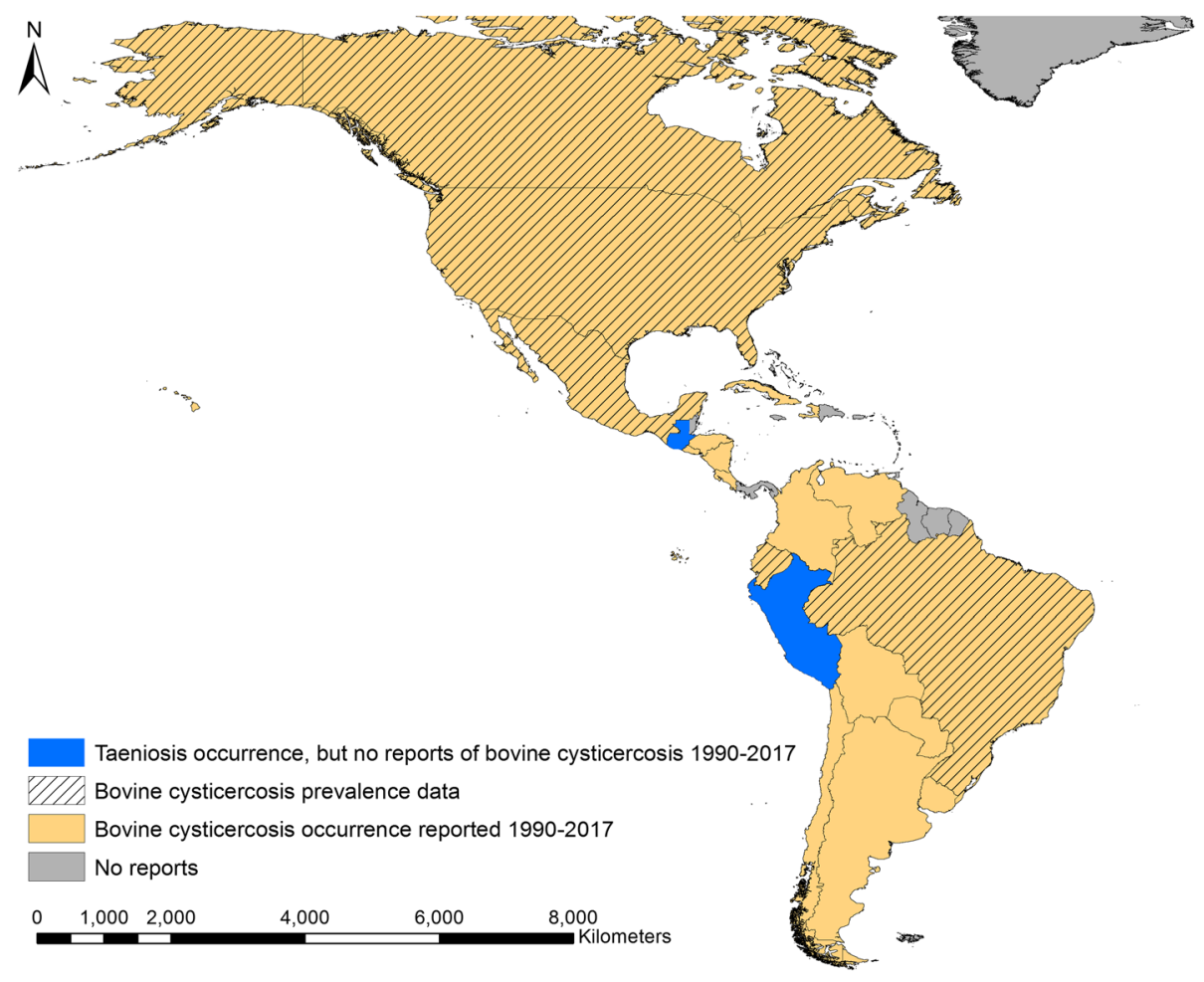

Fig. 3 Bovine cysticercosis occurrence and countries with studies reporting prevalence in the period 1990-2017

the number of animals within a farm [17], spatial modelling of livestock density could therefore be considered as a first step in estimating areas of risk, such as previously done for T. solium [18]. Detailed mapping studies with prevalence of bovine cysticercosis are warranted for all endemic countries; however, such studies only seem to have been performed in Brazil. Bovine cysticercosis prevalence based on meat inspection ranged from very low levels to almost $19 \%$, which is a higher range than recent reports from Europe $(<5 \%)$ [8], the Middle East $(3 \%)[19]$ and Africa $(<4 \%)[20,21]$.

Table 4 Reported occurrence of bovine cysticercosis (case studies/published data without full prevalence or incidence data) based on meat inspection

\begin{tabular}{lllll}
\hline Country & Year & Location of study $^{\text {a }}$ & Cases & Reference \\
\hline Brazil & na & Minas Gerais & na & {$[59]$} \\
Brazil & $2005-2006$ & Goias & na & {$[60]$} \\
Brazil & $2009-2010$ & Minas Gerais & 2019 & {$[61]$} \\
Brazil & $2008-2010$ & Espírito Santo & na & {$[62]$} \\
Chile & 2010 & na & 148 & {$[63]$} \\
Cuba & $1998-2001$ & Villa Clara & na & {$[64]$} \\
USA & $1985-1994$ & Nationwide & na & {$[23]$} \\
US Virgin Islands & 1992 & na & na & {$[23]$} \\
\hline Abbrevation: na & & &
\end{tabular}

Abbreviation: na information not provided

${ }^{\text {a }}$ First-level administration
Only five countries on the mainland (Belize, French Guiana, Guyana, Suriname and Panama) did not have reports of taeniosis or bovine cysticercosis. All five countries have cattle industries and in 2016 had an estimated number of cattle: 110,024 in Belize, 18,945 in French Guiana, 10,115 in Guyana, 36,138 in Suriname, and 1,554,200 in Panama [22]. Due to reports of bovine cysticercosis from neighbouring countries, the missing reports could be a result of underreporting rather than absence of the parasite in these populations. Epidemiological surveys should be performed in these five countries in order to confirm or refute the absence of $T$. saginata. The lack of reports of $T$. saginata from the smaller Caribbean islands, except for one case from the US Virgin Islands in 1994 [23], could suggest that infection pressure is insufficient to sustain transmission on these islands and reports are a result of small self-limiting outbreaks resulting from imported taeniosis cases. Cattle populations are relatively small on the Caribbean islands with many islands slaughtering less than 1000 cattle annually [22], which would likely mitigate any potential outbreak to burn out quickly. However, bovine cysticercosis was found on the two largest Caribbean islands (Cuba and Hispaniola). On Hispaniola, bovine cysticercosis was only reported in Haiti (Fig. 4); thus, investigations to explore the situation in the Dominican Republic are highly warranted. 
Table 5 Prevalence of bovine cysticercosis (published data)

\begin{tabular}{|c|c|c|c|c|c|c|}
\hline Country & Year & Location of study $^{\mathrm{a}}$ & Time frame & Prevalence $(95 \% \mathrm{Cl})$ & Diagnostic technique & Reference \\
\hline Brazil & 2013 & Minas Gerais & Jan-Jun & $2.1(2.01-2.22)$ & Meat inspection & {$[65]$} \\
\hline Brazil & 2006-2007 & Bahia & na & $0.7(0.64-0.67)$ & Meat inspection & {$[66]$} \\
\hline Brazil & 2004 & Minas Gerais & na & $3.2(3.00-3.48)$ & Meat inspection & [67] \\
\hline Brazil & na & Mato Grosso do Sul & na & $18.8(11.51-28.00)$ & Meat inspection & [68] \\
\hline Brazil & 2000 & Paraná & Jul-Dec & $3.8(3.60-4.07)$ & Meat inspection & [69] \\
\hline \multirow[t]{2}{*}{ Brazil } & 2013 & Minas Gerais & Jul-Aug & $15.1(12.91-17.44)$ & Ab-ELISA & [70] \\
\hline & & & & $4.7(3.47-6.19)$ & Immunoblot & \\
\hline Brazil & 2007-2010 & Nationwide & Jan-Apr & $1.1(1.05-1.05)$ & Meat inspection & [71] \\
\hline Brazil & 2010-2015 & Nationwide & Jan-Dec & $0.6(0.62-0.62)$ & Meat inspection & {$[72]$} \\
\hline Brazil & 2004 & Paraná & Jan-Dec & $9.3(6.57-12.58)$ & Meat inspection & [73] \\
\hline Brazil & 2010-2011 & São Paulo & Oct-Aug & $4.8(4.58-5.04)$ & Meat inspection & [74] \\
\hline Brazil & $2003-2004$ & Rio de Janeiro & Jan-Dec & $2.3(2.07-2.45)$ & Meat inspection & {$[75]$} \\
\hline \multirow[t]{2}{*}{ Brazil } & na & Minas Gerais & na & $10.6(7.55-14.40)$ & Ab-ELISA & {$[76]$} \\
\hline & & & & $4.1(2.28-6.83)$ & Immunoblot & \\
\hline Brazil & 2004-2008 & Paraná & Jan-Dec & $2.2(2.22-2.24)$ & Meat inspection & [77] \\
\hline Brazil & 1997-2003 & Rio de Janeiro & Jan-Dec & $2.0(1.91-1.99)$ & Meat inspection & [78] \\
\hline \multirow[t]{4}{*}{ Brazil } & 2012 & São Paulo & Jan-Dec & $2.9(2.83-3.03)$ & Meat inspection & [79] \\
\hline & & Minas Gerais & & $1.8(1.71-1.93)$ & & \\
\hline & & Goias & & $0.7(0.61-0.82)$ & & \\
\hline & & Mato Grosso do Sul & & $1.1(0.77-1.58)$ & & \\
\hline Brazil & 2013-2014 & Mato Grosso & Jan-Dec & $0.1(0.09-0.09)$ & Meat inspection & [80] \\
\hline Brazil & 2009 & Minas Gerais & na & $2.5(0.92-5.36)$ & Ab-ELISA & [81] \\
\hline Brazil & 2009-2010 & Bahia & Jan-Jan & $3.6(3.43-3.69)$ & Meat inspection & {$[82]$} \\
\hline Brazil & 2008 & Goiás & Jan-Dec & $0.7(0.67-0.73)$ & Meat inspection & [83] \\
\hline Brazil & 2000 & Parana & Jul-Dec & $3.8(3.60-4.07)$ & Meat inspection & [84] \\
\hline Brazil & 2009-2013 & Rio Grande do Sul & Jan-Dec & $2.5(2.28-2.78)$ & Meat inspection & [85] \\
\hline Brazil & 2011-2013 & Rio Grande do Sul \& Tocantins & Jan-Apr & $5.0(2.80-8.03)$ & Meat inspection & {$[86]$} \\
\hline Brazil & na & Paraíba & na & $2.7(2.11-3.46)$ & Ab-ELISA & [87] \\
\hline Canada & 1992 & Ontario & Oct; Dec & $5.8(4.81-6.82)$ & Meat inspection & [88] \\
\hline Canada & 2000 & Alberta & Apr & $7.9(4.02-13.72)$ & Meat inspection & [89] \\
\hline \multirow[t]{4}{*}{ Ecuador } & $2000-2001$ & Imbabura; Pichincha & Dec-Jan & $5.8(3.71-8.57)$ & Ag-ELISA & [47] \\
\hline & & & & $0.3(0.01-1.48)$ & Meat inspection & \\
\hline & & & & $2.5(1.32-4.40)$ & Ag-ELISA & \\
\hline & & & & $0.5(0.06-1.66)$ & Meat inspection & \\
\hline Mexico & 2008-2009 & Nationwide & Oct-Jul & $0.2(0.17-0.25)$ & Meat inspection & [90] \\
\hline USA & 1992-1993 & Idaho & May-May & $8.9(8.09-9.66)$ & Meat inspection & [91] \\
\hline
\end{tabular}

Abbreviations: $\mathrm{Cl}$ confidence interval, na information not provided

There are clear diagnostic issues in terms of both taeniosis and bovine cysticercosis. The sensitivity of meat inspection for bovine cysticercosis can be increased to some extent by making more incisions into organs and muscles of the carcass. However, the risk of contaminating the carcass with microbes that pose a risk to food safety is correlated with the number of incisions made
[24]. Since the health risk in $T$. saginata infections are minimal, compared to those of bacterial pathogens for example, an increase of the number of incisions might be unwise or should perhaps be completely avoided under certain circumstances. However, more incisions in the heart has been shown to increase the sensitivity for the diagnosis of bovine cysticercosis compared to the 


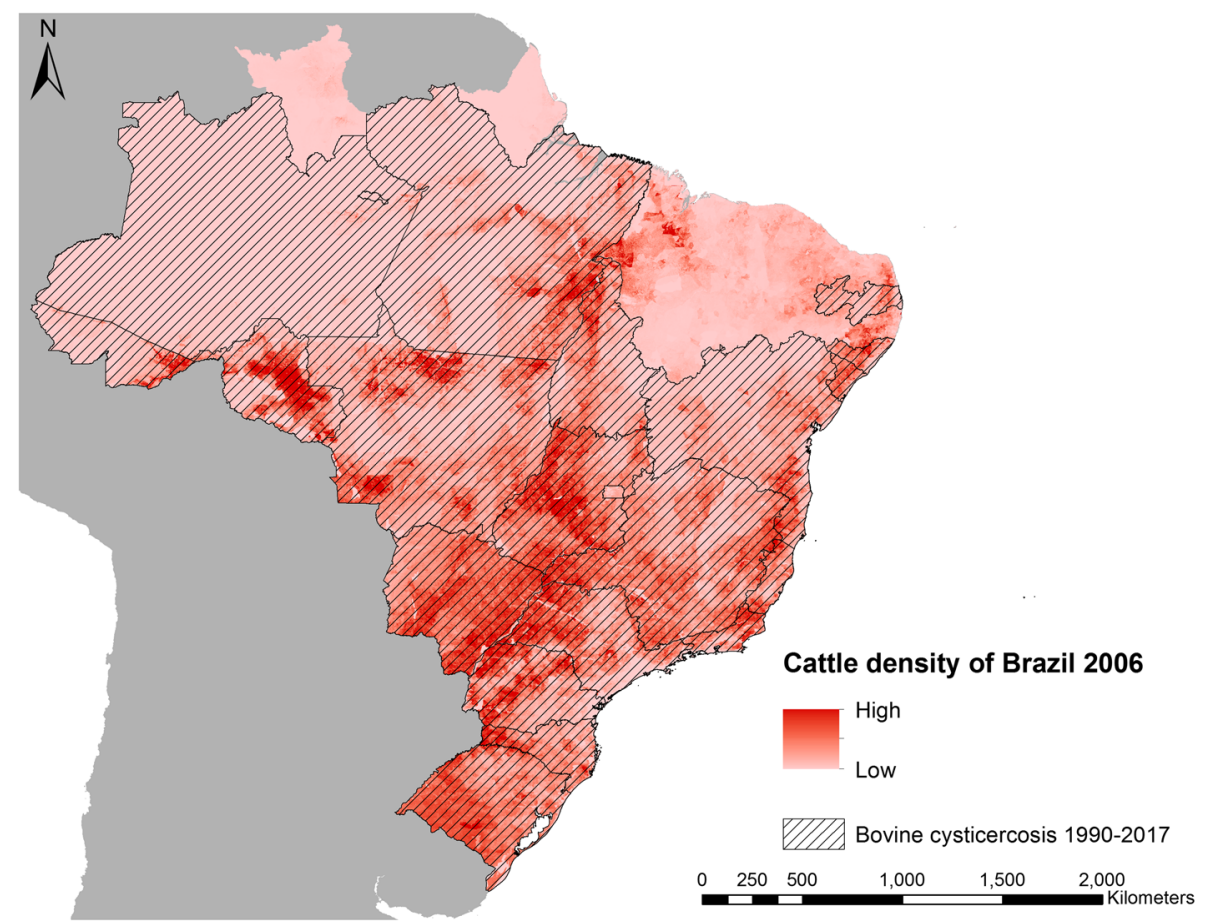

Fig. 4 States in Brazil with bovine cysticercosis during 1990-2017 and the modelled cattle density for Brazil in 2006 [12]

EU-approved routine meat inspection [25]. Still, more research is required to determine whether meat inspection procedures should be changed and what consequences it will have for areas of low and high bovine cysticercosis endemicity, respectively. Another approach to reduce transmission risk could be risk-based meat inspection in countries where appropriate herd level data is obtainable [26].

Taenia saginata is prevalent in countries where sanitation standards are high [8], suggesting that elimination of this parasite is extremely difficult. Epidemiological surveys and mapping studies should be performed in all endemic countries in order to evaluate the distribution and the economic burden of T. saginata and to assess whether cost-effective intervention measures can be implemented. Standard goals should be put forward in terms of describing a protocol for estimating the distribution, prevalence, incidence and the economic burden of bovine cysticercosis. Based on the economic analyses, cost-effective measures can then be implemented, if appropriate, in the efforts to control T. saginata.

\section{Conclusions}

Taenia saginata is widely distributed across the Americas, but the epidemiological data available are insufficient to estimate the subnational spatial distribution, prevalence, incidence and intensity of infections. This needs to be addressed through active surveillance and disease detection programmes. Such programmes would ameliorate the lack of data needed to quantify the economic burden bovine cysticercosis imposes on the region. These issues should be addressed in order to assess the need and advocate for implementation of cost-effective control measures against $T$. saginata if necessary.

\section{Additional files}

Additional file 1: Review protocol and PRISMA checklist. (PDF 527 kb) Additional file 2: Table S1. Identified literature supporting the presence of Taenia saginata in the Americas during 1990-2017. Table S2. States in Brazil with bovine cysticercosis in 1990-2017. Table S3. Countries in the Americas with Taenia saginata occurrence in 1990-2017. (XLSX 37 kb)

\section{Abbreviation \\ Cl: Confidence interval}

\section{Acknowledgments}

This work was a collaboration within the framework of CYSTINET, the European network on taeniasis/cysticercosis, COST ACTION TD1302 and members of the T. saginata working group: Branko Bobic, Paul Torgerson and Ramon Eichenberger.

\section{Availability of data and materials}

All references found eligible in our literature review are included in the article.

\section{Authors' contributions}

UCB conducted the systematic review of literature, extracted and analysed the data and drafted the first version of the manuscript. All authors contributed to the design of the study, interpretation of the data, and writing the paper. All authors read and approved the final manuscript. 


\section{Ethics approval and consent to participate}

Not applicable.

\section{Consent for publication}

Not applicable.

\section{Competing interests}

The authors declare that they have no competing interests.

\section{Publisher's Note}

Springer Nature remains neutral with regard to jurisdictional claims in published maps and institutional affiliations.

\section{Author details}

'One Health Center for Zoonoses and Tropical Veterinary Medicine, Ross University School of Veterinary Medicine, P.O. Box 334, Basseterre, Saint Kitts and Nevis. International Livestock Research Institute (ILRI), P.O. Box 30709, Nairobi, Kenya. ${ }^{3}$ Institute for Infection \& Global Health, University of Liverpool, Neston, UK. ${ }^{4}$ Parasitology, Department of Food Safety and Infection Biology, Faculty of Veterinary Medicine, Norwegian University of Life Sciences, Adamstuen Campus, Oslo, Norway. ${ }^{5}$ Department of Biomedical Sciences, Institute of Tropical Medicine, Antwerp, Belgium. 'Department of Virology, Parasitology and Immunology, Faculty of Veterinary Medicine, Ghent University, Merelbeke, Belgium. Veterinary Research Institute, Hellenic Agricultural Organization Demeter, 57001 Thermi, Greece. ${ }^{8}$ Department of Epidemiology and Public Health, Sciensano, Brussels, Belgium. ${ }^{9}$ Department of Veterinary Public Health and Food Safety, Faculty of Veterinary Medicine, Ghent University, Merelbeke, Belgium.

\section{Received: 13 April 2018 Accepted: 27 August 2018}

Published online: 20 September 2018

\section{References}

1. Boone I, Thys E, Marcotty T, de Borchgrave J, Ducheyne E, Dorny P. Distribution and risk factors of bovine cysticercosis in Belgian dairy and mixed herds. Prev Vet Med. 2007:82:1-11.

2. Tembo A, Craig PS. Taenia saginata taeniosis: copro-antigen time-course in a voluntary self-infection. J Helminthol. 2015;89:612-9.

3. Jansen F, Dorny P, Berkvens D, Van Hul A, Van den Broeck N, Makay C, et al. High prevalence of bovine cysticercosis found during evaluation of different post-mortem detection techniques in Belgian slaughterhouses. Vet Parasitol. 2017;244:1-6.

4. Dorny P, Vercammen F, Brandt J, Vansteenkiste W, Berkvens D, Geerts S. Sero-epidemiological study of Taenia saginata cysticercosis in Belgian cattle. Vet Parasitol. 2000;88:43-9.

5. Kyvsgaard N, Ilsoe B, Henriksen SA, Nansen P. Distribution of Taenia saginata cysts in carcases of experimentally infected calves and its significance for routine meat inspection. Res Vet Sci. 1990;49:29-33.

6. Eichenberger $R$, Lewis F, Gabriël S, Dorny P, Torgerson P, Deplazes P. Multitest analysis and model-based estimation of the prevalence of Taenia saginata cysticercus infection in naturally infected dairy cows in the absence of a 'gold standard'reference test. Int J Parasitol. 2013;43:853-9.

7. Ilsoe B, Kyvsgaard NC, Nansen P, Henriksen SA. A study on the survival of Taenia saginata eggs on soil in Denmark. Acta Vet Scand. 1990;31:153-8.

8. Laranjo-Gonzalez M, Devleesschauwer B, Gabriel S, Dorny P, Allepuz A. Epidemiology, impact and control of bovine cysticercosis in Europe: a systematic review. Parasit Vectors. 2016;9:81.

9. Moher D, Liberati A, Tetzlaff J, Altman DG, PRISMA Group. Preferred reporting items for systematic reviews and meta-analyses: The PRISMA statement. PLoS Med. 2009;6:e1000097.

10. OIE. World Animal Health Information Database (WAHID) Interface. 2018.

11. OIE. World Animal Health in 1995. Paris: Office International des Epizooties; 1996.

12. Robinson TP, Wint GR, Conchedda G, Van Boeckel TP, Ercoli V, Palamara E, et al. Mapping the global distribution of livestock. PLoS One. 2014;9:e96084.

13. Gherman I. Observations on treatment of taeniasis by N-(2'-chloro-4'nitrophenyl)-5-chlorosalicylamide. Bull Soc Pathol Exot Filiales. 1968:61:432.

14. Pawłowski ZS. Efficacy of low doses of praziquantel in taeniasis. Acta Trop. 1990;48:83-8.

15. Praet N, Verweij JJ, Mwape KE, Phiri IK, Muma JB, Zulu G, et al. Bayesian modelling to estimate the test characteristics of coprology, coproantigen
ELISA and a novel real-time PCR for the diagnosis of taeniasis. Tropical Med Int Health. 2013;18:608-14.

16. Dorny P, Praet N. Taenia saginata in Europe. Vet Parasitol. 2007;149:22-4.

17. Allepuz A, Napp S, Picado A, Alba A, Panades J, Domingo M, Casal J. Descriptive and spatial epidemiology of bovine cysticercosis in northeastern Spain (Catalonia). Vet Parasitol. 2009;159:43-8.

18. Braae UC, Devleesschauwer B, Sithole F, Wang Z, Willingham AL. Mapping occurrence of Taenia solium taeniosis/cysticercosis and areas at risk of porcine cysticercosis in Central America and the Caribbean basin. Parasit Vectors. 2017:10:424.

19. Garedaghi Y, Saber AR, Khosroshahi MS. Prevalence of bovine cysticercosis of slaughtered cattle in Meshkinshahr Abattoir. Am J Anim Vet Sci. 2011;6:121-4

20. Asaava LL, Kitala PM, Gathura PB, Nanyingi MO, Muchemi G, Schelling E. A survey of bovine cysticercosis/human taeniosis in Northern Turkana District, Kenya. Prev Vet Med. 2009;89:197-204.

21. Ibrahim N, Zerihun F. Prevalence of Tania saginata cysticercosis in cattle slaughtered in Addis Ababa Municipal Abattoir, Ethiopia. Glob Vet. 2012:8:467-71.

22. FAO. Food and Agriculture Organization of the United Nations statistical databases http://www.fao.org/faostat/en/\#data/QL. Accessed 9 Sept 2018.

23. Saini PK, Webert DW, McCaskey PC. Food safety and regulatory aspects of cattle and swine cysticercosis. J Food Prot. 1997;60:447-53.

24. Buncic S, Nychas G-J, Lee MR, Koutsoumanis K, Hébraud M, Desvaux M, et al. Microbial pathogen control in the beef chain: recent research advances. Meat Sci. 2014;97:288-97.

25. Eichenberger RM, Stephan R, Deplazes P. Increased sensitivity for the diagnosis of Taenia saginata cysticercus infection by additional heart examination compared to the EU-approved routine meat inspection. Food Control. 2011:22:989-92.

26. Blagojevic B, Robertson LJ, Vieira-Pinto M, Johansen MV, Laranjo-González M, Gabriël S. Bovine cysticercosis in the European Union: impact and current regulations, and an approach towards risk-based control. Food Control. 2017:78:64-71.

27. Sartorelli AC, da Silva MG, Rodrigues MA, da Silva RJ. Appendiceal taeniasis presenting like acute appendicitis. Parasitol Res. 2005;97:171-2.

28. Schenone $\mathrm{H}$, Schenone S, Arriagada J. Eliminacion oral de segmentos de estrobila de Taenia saginata. Bol Chil Parasitol. 1992;47:33-5.

29. Marquez-Navarro A, Cornejo-Coria Mdel C, Cebada-Lopez F, SanchezManzano RM, Diaz-Chiguer DL, Nogueda-Torres B. Taenia saginata: failure treatment in a child with 5-year long-lasting infection. Gastroenterol Nurs. 2012;35:125-7.

30. Jeske S, Bianchi TF, Moura MQ, Baccega B, Pinto NB, Berne MEA, Villela MM. Intestinal parasites in cancer patients in the South of Brazil. Braz J Biol. 2017;78:574-8.

31. Rodriguez-Morales AJ, Yepes-Echeverri MC, Acevedo-Mendoza WF, MarinRincon HA, Culquichicon C, Parra-Valencia E, et al. Mapping the residual incidence of taeniasis and cysticercosis in Colombia, 2009-2013, using geographical information systems: implications for public health and travel medicine. Travel Med Infect Dis. 2017;22:51-7.

32. de Kaminsky RG. Albendazole treatment in human taeniasis. Trans R Soc Trop Med Hyg. 1991;85:648-50.

33. Bustos JA, Rodriguez S, Jimenez JA, Moyano LM, Castillo Y, Ayvar V, et al. Detection of Taenia solium taeniasis coproantigen is an early indicator of treatment failure for taeniasis. Clin Vaccine Immunol. 2012;19:570-3.

34. Jeri C, Gilman $\mathrm{RH}$, Lescano AG, Mayta H, Ramirez ME, Gonzalez AE, et al. Species identification after treatment for human taeniasis. Lancet. 2004:363:949-50.

35. Acurero E, Diaz I, Diaz N, Bracho A, Ferrer M, Matheus A. Prevalence of enteroparasitism in pregnant women at the "Dr. Armando Castillo Plaza" Maternity Center, Maracaibo, Venezuela. Kasmera. 2008;36:148-58.

36. Benitez JA, Rodriguez-Morales AJ, Vivas P, Plaz J. Burden of zoonotic diseases in Venezuela during 2004 and 2005. Ann N Y Acad Sci. 2008; 1149:315-7.

37. Borda CE, Rea MJ, Rosa JR, Maidana C. Intestinal parasitism in San Cayetano, Corrientes, Argentina. Bull Pan Am Health Organ. 1996;30:227-33.

38. Milano AM, Oscherov EB, Palladino AC, Bar AR. Enteroparasitosis infantil en un area urbana del nordeste Argentino. Medicina. 2007;67:238-42.

39. Carvalho Odos S, Guerra HL, Campos YR, Caldeira RL, Massara CL. Prevalencia de helmintos intestinais em tres mesorregioes do Estado de Minas Gerais. Rev Soc Bras Med Trop. 2002;35:597-600.

40. Esteves FM, Silva-Vergara ML, Carvalho AC. Inquerito epidemiologico sobre teniase em populacao do Programa Saude da Familia no municipio de Uberaba, MG. Rev Soc Bras Med Trop. 2005;38:5301. 
41. Neres-Norberg A, Guerra-Sanches F, Blanco Moreira-Norberg PR, MadeiraOliveira JT, Santa-Helena AA, Serra-Freire NM. Enteroparasitismo en indigenas terena en el Estado de Mato Grosso do Sul, Brasil. Rev Salud Publica. 2014;16:859-70.

42. Santos SA, Merlini LS. Prevalencia de enteroparasitoses na populacao do municipio de Maria Helena, Parana. Cien Saude Colet. 2010;15:899-905.

43. Silva-Vergara ML, Prata A, Netto HV, Vieira Cde O, Castro JH, Micheletti LG, et al. Risk factors associated with taeniasis-cysticercosis in Lagamar, Minas Gerais State, Brazil. Rev Soc Bras Med Trop. 1998;31:65-71.

44. Silva-Vergara ML, Prata A, Vieira Cde O, Castro JH, Micheletti LG, Otano AS, Franquini J Jr. Aspectos epidemiologicos da teniase-cisticercose na area endemica de Lagamar, MG. Rev Soc Bras Med Trop. 1995;28:345-9.

45. Vidal S, Toloza L, Cancino B. Evolution of the prevalence the enteroparasitoses in Talca - Chile. Rev Chil Infectol. 2010;27:336-40.

46. Agudelo-Lopez S, Gomez-Rodriguez L, Coronado X, Orozco A, ValenciaGutierrez CA, Restrepo-Betancur LF, et al. Prevalencia de parasitosis intestinales y factores asociados en un corregimiento de la Costa Atlantica Colombiana. Rev Salud Publica. 2008;10:633-42.

47. Rodriguez-Hidalgo R, Benitez-Ortiz W, Dorny P, Geerts S, Geysen D, RonRoman J, et al. Taeniosis-cysticercosis in man and animals in the Sierra of northern Ecuador. Vet Parasitol. 2003;118:51-60.

48. Allan JC, Mencos F, Garcia-Noval J, Sarti E, Flisser A, Wang Y, et al. Dipstick dot ELISA for the detection of Taenia coproantigens in humans. Parasitology. 1993;107:79-85.

49. Allan JC, Velasquez-Tohom M, Garcia-Noval J, Torres-Alvarez R, Yurrita P, Fletes C, et al. Epidemiology of intestinal taeniasis in four, rural, Guatemalan communities. Ann Trop Med Parasitol. 1996;90:157-65.

50. Champetier de Ribes G, Fline M, Desormeaux AM, Eyma E, Montagut $P$, Champagne $C$, et al. Helminthoses intestinales en milieu scolaire en Haiti en 2002. Bull Soc Pathol Exot. 2005;98:127-32.

51. Sanchez AL, Medina MT, Ljungstrom I. Prevalence of taeniasis and cysticercosis in a population of urban residence in Honduras. Acta Trop. 1998;69:141-9.

52. Behravesh CB, Mayberry LF, Bristol JR, Cardenas VM, Mena KD, MartinezOcana J, et al. Population-based survey of taeniasis along the United StatesMexico border. Ann Trop Med Parasitol. 2008;102:325-33.

53. Huh S, Ahn C, Chai JY. Intestinal parasitic infections in the residents of an emigration camp in Tijuana, Mexico. Korean J Parasitol. 1995;33:65-7.

54. Martinez-Maya JJ, de Aluja AS, Avila-Ramirez G, Aguilar-Vega L, PlancarteCrespo A, Jaramillo-Arango CJ. Taeniosis and detection of antibodies against cysticerci among inhabitants of a rural community in Guerrero State, Mexico. Salud Publica Mex. 2003:45:84-9.

55. Sarti E, Schantz PM, Avila G, Ambrosio J, Medina-Santillan R, Flisser A. Mass treatment against human taeniasis for the control of cysticercosis: a population-based intervention study. Trans R Soc Trop Med Hyg. 2000;94:85-9.

56. Cordero A, Miranda E, Segovia G, Cantoral V, Huarcaya I. Prevalencia de teniosis y seroprevalencia de cisticercosis humana en Pampa Cangallo, Ayacucho, Peru 2008. Rev Peru Med Exp Salud Publica. 2010;27:562-8.

57. O'Neal SE, Moyano LM, Ayvar V, Gonzalvez G, Diaz A, Rodriguez S, et al. Geographic correlation between tapeworm carriers and heavily infected cysticercotic pigs. PLoS Negl Trop Dis. 2012;6:e1953.

58. Meza NW, Rossi NE, Galeazzi TN, Sanchez NM, Colmenares FI, Medina OD, et al. Cysticercosis in chronic psychiatric inpatients from a Venezuelan community. Am J Trop Med Hyg. 2005;73:504-9.

59. Goncalves FD, Machado GA, Oliveira HB, Rezende M, Mineo JR, Costa-Cruz JM. Hydrophobic fraction of Taenia saginata metacestodes, rather than hydrophilic fraction, contains immunodominant markers for diagnosing human neurocysticercosis. Rev Soc Bras Med Trop. 2010;43:254-9.

60. EAGdV J, VBL M, Vinaud MC, RdS LJ, GFC L. Molecular identification of Cysticercus bovis at different stages of the host-parasite interaction process. Rev Patol Trop. 2011;40:331-40.

61. Morais HR, Pirtouscheg A, Moreira MD, Tavares M. Interrelation between viability of Cysticercus bovis and organs of encystment in bovine cattle from Triângulo Mineiro. PUBVET. 2011;5:1037.

62. Vieira NP, Faria PB, Mattos MR, Pereira AA. Condemnation of bovine liver in the southern region of the State Espirito Santo, Brazil. Arq Bras Med Vet Zoo. 2011:63:1605-8.

63. Cayo F, Valenzuela G, Paredes E, Ruiz V, Gallo C. Distribution and viability of cyticerci of Taenia saginata in meat cuts from naturally infected beef. Arch Med Vet. 2013;45:207-12
64. PFdl R, Alberto EB, Alonso LR, MdC Q. Considerations on the cycle of Taenia saginata in humans and bovines of the province Villa Clara, Cuba. REDVET. 2006;7:040607.

65. Assunção EF, Ferreira IM, Braga HF. Bovine cysticercosis and tuberculosis prevalence in an exporter slaughterhouse of Campina Verde, MG. PUBVET. 2014;8:1783.

66. Bavia ME, Carneiro D, Cardim LL, Silva MMN, Martins MS. Spatial scan statistic in the detection of risk areas for bovine cysticercosis in the state of Bahia. Arq Bras Med Vet Zoo. 2012;64:1200-8.

67. Costa RFR, Santos IF, Santana AP, Tortelly R, Nascimento ER, Fukuda RT, et al. Characterization of Cysticercus bovis lesions at postmortem inspection of cattle by gross examination, histopathology and polymerase chain reaction (PCR). Pesqui Vet Bras. 2012;32:477-84.

68. de Aragao SC, Biondi GF, Lima LGF, Nunes CM. Animal cysticercosis in indigenous Brazilian villages. Rev Bras Parasitol Vet. 2010;19:132-4.

69. de Souza VK, Pessoa-Silva Mdo C, Kowalczuk M, Marty S, Thomaz-Soccol V. Regioes anatomicas de major ocorrencia de Cysticercus bovis em bovinos submetidos a inspecao federal em matadouro-frigorifico no municipio de Sao Jose dos Pinhais, Parana, de Julho a Dezembro de 2000. Rev Bras Parasitol Vet. 2007;16:92-6.

70. Duarte CTD, Pinto PSA, Silva LF, Santos TO, Acevedo-Nieto EC, Almeida LP. Transmission and prevalence profile of bovine cysticercosis in rural properties of Triangulo Mineiro, Brazil. Pesqui Vet Bras. 2016;36:793-7.

71. Dutra LH, Girotto A, RFdC V, TSWJ V, Zangirolamo AF, FAC M, et al. The prevalence and spatial epidemiology of cysticercosis in slaughtered cattle from Brazil. Semin Cienc Agrar. 2012;33:1887-96.

72. Rossi GAM, Martins IVF, Campos RF, Soares LFS, Almeida HMS, Mathias LA. Spatial distribution of bovine cysticercosis - a retrospective study in Brazil from 2010 through 2015. Prev Vet Med. 2017;145:145-9.

73. Falavigna-Guilherme AL, Silva K, Araújo SM, Tobias ML, Falavigna DLM. Cisticercose em animais abatidos em Sabáudia, Estado do Paraná. Arq Bras Med Vet Zoo. 2006:58:950-1.

74. Ferreira MM, Revoredo TB, Ragazzi JP, Soares VE, Ferraldo AS, RPd M, WDZ L. Prevalence, spatial distribution and risk factors for cattle cysticercosis in the state of São Paulo, Brazil. Pesqui Vet Bras. 2014;34:1181-5.

75. Garcia LN, Pereira MA, Miranda FJ, Gomes FF, Resende MA, Lira BR. Cysticercus bovis em bovinos abatidos sob servico de inspecao federalna regiao serrana do Estado do Rio de Janeiro em 2003 e 2004. Rev Bras Parasitol Vet. 2008;17(Suppl. 1):170-1.

76. Garro FL, Santos TM, Assis DCS, Heneine LGD, Ornellas CBD, Pinto PSA, Santos WLM. Diagnosis of bovine taeniasis-cysticercosis complex in Sao Joao Evangelista, Minas Gerais, Brazil. Arq Bras Med Vet Zoo. 2015;67:1063-9.

77. Guimaraes-Peixoto RPM, Souza VK, Pinto PSA, Santos TO. Distribution and identification of risk areas for bovine cysticercosis in the State of Parana, Brazil. Pesqui Vet Bras. 2012;32:975-9.

78. Pereira MAVC, Schwanz VS, Barbosa CG. Prevalence of cysticercosis in bovine carcasses in slaughterhouses and cold stores in Rio de Janeiro State, Brazil, submitted to the federal surveillance service (SIF-RJ) from 1997 to 2003. Arq Inst Biol (Sao Paulo). 2006;73:83-7.

79. Rossi GA, Hoppe EG, Mathias LA, Martins AM, Mussi LA, Prata LF. Bovine cysticercosis in slaughtered cattle as an indicator of Good Agricultural Practices (GAP) and epidemiological risk factors. Prev Vet Med. 2015; 118:504-8.

80. Rossi GAM, HASd S, WDZ L, HMdS A, Soares VE, AMC V, et al. Prevalence and geospatial distribution of bovine cysticercosis in the state of Mato Grosso, Brazil. Prev Vet Med. 2016;130:94-8.

81. Santos TO, Pinto PSA, lasbik AF, Silva LF, Nieto ECA, Guimaraes-Peixoto RPM. Epidemiological survey of the taeniasis/cysticercosis complex in cattle farms in Vicosa County, Minas Gerais, Brazil. Pesqui Vet Bras. 2013;33:449-52.

82. Silva DR, Albuquerque GR. Cysticercosis in cattle slaughtered under State Inspection in the municipality of Vitoria da Conquista, BA. Rev Bras Med Vet. 2010;32:225-8.

83. Silveira Neto OJd, Oliveira RRd, Pereira FdO, Basile ÂLdC, Taveira RZ. Occurrence and location of Cysticercus bovis in cattle submitted to Federal Inspection in slaughterhouse in Goias, Brazil. PUBVET. 2011;5:21.

84. Souza VK, Pessoa-Silva MD, Minozzo JC, Thomaz-Soccol V. Bovine cysticercosis prevalence in Parana State, southern of Brazil, in animals slaughtered under the SIF 1710. Semin Cienc Agrar. 2007;28:675-83.

85. Teixeira JLR, Recuero ALC, Brod CS. Ambispective cohort study of bovine cysticercosis from slaughterhouses with Municipal Inspection Service (SIM) in the southern Rio Grande do Sul, Brazil. Rev Patol Trop. 2015;44:146-54. 
86. Tessele B, Brum JS, Barros CSL. Parasitic lesions observed in cattle slaughtered for human consumption. Pesqui Vet Bras. 2013;33:873-89.

87. Maia ARA, Fernandes LG, Pinto PSA, Guimaraes-Peixoto RPM, Silva LF, Santos $C$, et al. Herd-level seroprevalence and associated risk factors for bovine cysticercosis in the State of Paraiba, northeastern Brazil. Prev Vet Med. 2017; 142:51-7.

88. Borman-Eby HA, Ayim DS, Small C. Cysticercus bovis in cattle in two beef feedlots in southern Ontario. Can Vet J. 1994;35:711-3.

89. Lees W, Nightingale J, Brown D, Scandrett B, Gajadhar A. Outbreak of Cysticercus bovis (Taenia saginata) in feedlot cattle in Alberta. Can Vet J. 2002:43:227-8

90. Gonzalez SAC, Castillo JLR, Valencia GL, Hurtado RMB, Robles ESH, Navarro FJM. Prevalence of Taenia saginata larvae (Cysticercus bovis) in feedlot cattle slaughtered in a federal inspection type abattoir in northwest Mexico. Foodborne Pathog Dis. 2015;12:462-5.

91. Yoder DR, Ebel ED, Hancock DD, Combs BA. Epidemiologic findings from an outbreak of cysticercosis in feedlot cattle. J Am Vet Med Assoc. 1994; 205:45-50.

Ready to submit your research? Choose BMC and benefit from:

- fast, convenient online submission

- thorough peer review by experienced researchers in your field

- rapid publication on acceptance

- support for research data, including large and complex data types

- gold Open Access which fosters wider collaboration and increased citations

- maximum visibility for your research: over $100 \mathrm{M}$ website views per year

At $\mathrm{BMC}$, research is always in progress.

Learn more biomedcentral.com/submissions 